\title{
KAJIAN KUAT TARIK BELAH DAN MODULUS OF RUPTURE PADA BETON MUTU TINGGI MEMADAT MANDIRI DENGAN BAHAN TAMBAH METAKAOLIN DAN VARIASI PERBANDINGAN AKTIVATOR ALKALI
}

\author{
Wibowo $^{1)}$, Endah Safitri ${ }^{2)}$, Dika Saputri ${ }^{3)}$ \\ 1),2) Dosen Program Studi Teknik Sipil, Fakultas Teknik, Universitas Sebelas Maret Surakarta \\ 3) Mahasiswa Program Studi Teknik Sipil, Fakultas Teknik, Universitas Sebelas Maret Surakarta \\ J1 Ir. Sutami 36A, Surakarta 57126. Telp: (0271) 634524, Fax 662118 \\ Email: dikasaputri7899@gmail.com
}

\begin{abstract}
The infrastructure construction in Indonesia will develop rapidly, so innovation of concrete will develop too. It aims to increase quality, strength, and durability of concrete. Metakaolin can be use as one of innovation for substitute cement on HSSCC because it kind of effective pozzolan and reactive. In order to more reactive, pozzolan can react with activator which from alkaline materials or called alkaline activator. Main goals of this study is how alkaline activator variations in high strength self-compacting concrete with 17,5\% metakaolin can affect SCC parameters, split tensile strength, and modulus of rupture from this concrete. This study use $\mathrm{NaOH}$ and $\mathrm{Na}_{2} \mathrm{SiO}_{3}$ as alkaline aktivator with ratio of $\mathrm{Na}_{2} \mathrm{SiO}_{3} / \mathrm{NaOH}$ is $0 ; 1 / 2$; 2/2; 3/2. SIKA Viscocrete 1003 used as superplasticizer. This study use beam without reinforcement with size $40 \mathrm{~cm} \times 10 \mathrm{~cm} \times 10 \mathrm{~cm}$ as sample for modulus of rupture test and cylinder with size $30 \mathrm{~cm}$ of height and $15 \mathrm{~cm}$ of diameter as sample for split tensile strength test. The result is addition of metakaolin $17,5 \%$ and ratio alkaline activator variations decrease workability of fresh concrete, but can fulfilled rules of self-compacting concrete in some variations. Maximum result of 28 days of concrete in parameter split tensile strength and modulus of rupture is 3,09 MPa and 3,57 MPa, which is using ratio 2/2 of alkaline activator.
\end{abstract}

Keywords: Alkaline activator, high strength self-compacting concrete, metakaolin, modulus of rupture, split tensile strength

\begin{abstract}
Abstrak
Pembangunan infrastruktur di Indonesia terus berkembang dengan cepat, sehingga inovasi dalam pembuatan beton juga semakin beragam. Hal ini bertujuan untuk meningkatkan mutu, kekuatan, dan durabilitas beton. Metakaolin dapat digunakan sebagai salah satu inovasi untuk mengganti penggunaan sebagian semen pada beton HSSCC karena merupakan pozzolan yang efektif dan reaktif. Agar lebih reaktif, pozzolan dapat direaksikan dengan aktivator yang berasal dari material alkali atau yang biasa disebut aktivator alkali. Tujuan utama dari penelitian yang telah dilakukan adalah bagaimana variasi aktivator alkali pada beton HSSCC dengan bahan tambah metakaolin 17,5\% dapat mempengaruhi parameter SCC, kuat tarik belah, dan modulus of rupture pada beton tersebut. Aktivator alkali menggunakan $\mathrm{NaOH}$ dan $\mathrm{Na}_{2} \mathrm{SiO}_{3}$ dengan perbandingan $\mathrm{Na}_{2} \mathrm{SiO}_{3} / \mathrm{NaOH}$ adalah $0 ; 1 / 2 ; 2 / 2 ; 3 / 2$. Superplasticizer yang digunakan adalah SIKA Viscocrete 1003. Benda uji pada penelitian ini balok beton tanpa tulangan dengan ukuran $400 \mathrm{~mm}$ × $100 \mathrm{~mm}$ x $100 \mathrm{~mm}$ untuk pengujian modulus of rupture, serta silinder beton dengan ukuran tinggi $300 \mathrm{~mm}$ dan diameter $150 \mathrm{~mm}$ untuk pengujian kuat tarik belah. Hasil pengujian menunjukkan bahwa penambahan aktivator alkali menurunkan workabilitas pada beton segar, namun dapat memenuhi syarat beton SCC pada perbandingan tertentu menurut EFNARC 2005. Hasil pengujian parameter kuat tarik belah dan modulus of rupture beton umur 28 hari tertinggi dicapai oleh beton dengan variasi aktivator alkali 2/2, yaitu sebesar 3,09 $\mathrm{MPa}$ dan 3,57 $\mathrm{MPa}$.
\end{abstract}

Kata Kunci : Aktivator alkali, beton mutu tinggi memadat mandiri, kuat tarik belah, metakaolin, modulus of rupture

\section{PENDAHULUAN}

Pembangunan infrastruktur di Indonesia kini berkembang dengan cepat. Hal ini terjadi karena jumlah penduduk yang bertambah, sehingga infrastruktur yang diperlukan semakin bertambah. Dengan adanya pembangunan infrastruktur dengan cepat, maka dibutuhkan bahan material dengan volume yang besar. Penggunaan beton Self Compacting Concrete (SCC) dapat menjadi solusi untuk mengatasi penurunan kualitas beton karena pemadatan yang tidak merata. Untuk mencapai kemampuan seperti ini, beton segar harus memenuhi syarat seperti filling ability, passing ability, dan segregation resistance. Pada pembuatan beton High Strength Self Compacting Concrete, kadar semen yang digunakan akan lebih banyak daripada pembuatan beton jenis lain, karena beton ini harus mencapai kuat tekan yang tinggi. Salah satu inovasi untuk mengurangi penggunaan semen pada pembuatan beton High Strength Self Com-

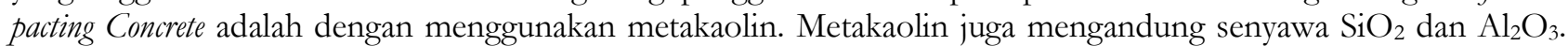
Karena mengandung Silika (Si) dan Alumunium (Al), metakaolin dapat diaktifkan oleh larutan alkali melalui reaksi polimerisasi untuk menghasilkan binder yang akan mengikat material lainnya. 
Metakaolin digunakan sebagai bahan tambah dalam penelitian ini. Metakaolin didapatkan dari hasil pembakaran kaolin selama 6 jam pada suhu $700^{\circ} \mathrm{C}$, sedangkan aktivator alkali yang digunakan adalah $\mathrm{NaOH}$ sebagai reaktan alkali dan $\mathrm{Na}_{2} \mathrm{SiO}_{3}$ sebagai katalisator. Metakaolin dan aktivator alkali ini akan bereaksi dan membentuk reaksi polimerisasi, sehingga akan mempengaruhi sifat mekanik beton, salah satunya adalah kuat tarik belah dan modulus of rupture. Namun, setelah melewati kadar optimumnya, kekuatannya dapat menurun. Hal ini sesuai dengan penelitian yang telah dilakukan oleh Risdanareni (2014).

Kuat tarik belah dengan benda uji beton berbentuk silinder adalah nilai kuat tarik tidak langsung dari benda uji beton berbentuk silinder yang diperoleh dari hasil pembebanan benda uji tersebut yang diletakkan mendatar sejajar dengan permukaan meja penekan mesin CTM. Sementara itu, modulus of rupture merupakan nilai kekuatan lentur maksimum pada beton yang didapatkan dari hasil pembebanan pada benda uji menggunakan mesin UTM.

Penelitian ini bertujuan untuk mengkaji pengaruh aktivator alkali terhadap hasil pengujian kuat tarik belah dan modulus of rupture pada High Strength Self Compacting Concrete dengan bahan tambah metakaolin. Variasi perbandingan $\mathrm{Na}_{2} \mathrm{SiO}_{3} / \mathrm{NaOH}$ yaitu $0 ; 1 / 2 ; 2 / 2 ;$ dan $3 / 2$.

\section{Landasan Teori}

Dalam SNI 2847:2019, beton didefinisikan sebagai bahan yang terbentuk dari campuran agregat kasar, semen, agregat halus, dan air, serta admixture (bahan tambah) bila digunakan. High Strength Concrete adalah beton mutu tinggi yang memiliki kuat tekan yang sama atau lebih besar dari 41,4 MPa. Syarat ini dicantumkan pada SNI 03-64682000 .

Beton jenis Self Compacting Concrete (SCC) adalah inovasi yang tidak memerlukan getaran untuk penempatan dan pemadatan beton. Karena tidak memerlukan getaran, kebisingan di lokasi pekerjaan dapat dikurangi. Beton ini mampu mengalir sendiri, mengisi bekisting, dan mencapai pemadatan penuh. Hal ini membuat beton jenis ini mampu membuat waktu pekerjaan konstruksi menjadi lebih cepat dan mudah mengalir pada tulangan yang padat (EFNARC 2005).

Metakaolin adalah hasil pembakaran (kalsinasi) kaolin yang dipanaskan pada suhu $600-900^{\circ} \mathrm{C}$ dan memiliki ukuran partikel yang lebih kecil dari silica fume. Metakaolin memiliki ukuran partikel yang kecil dan dapat mengisi ruang antar butiran sehingga memperkuat ikatan antar partikel. Kandungan $\mathrm{SiO}_{2}$ dan $\mathrm{Al}_{2} \mathrm{O}_{3}$ sangat banyak pada metakaolin. Kedua senyawa tersebut juga merupakan unsur utama yang terdapat pada semen. Oleh karena itu, metakaolin dapat digunakan sebagai bahan pengganti sebagian atau seluruh semen (Wibowo, et al., 2019).

Untuk melakukan reaksi polimerisasi, ion-ion yang tidak diperlukan perlu dilepaskan dengan dibantu oleh suatu reaktan dari golongan alkali. Reaktan alkali memiliki sifat basa kuat, kemudian dikombinasikan dengan alkali silikat yang berperan untuk mempercepat reaksi polimerisasi atau yang biasa disebut sebagai katalisator (Risdanareni, et al., 2014).

\section{METODE}

Langkah kerja yang runtut diperlukan pada penelitian ilmiah. Hal ini dilakukan agar hasil dari penelitian tersebut merupakan hasil yang rasional dan dapat dipertanggungjawabkan. Metode eksperimental digunakan dalam penelitian ini, yang akan menghasilkan data-data yang valid dan dapat membuktikan hubungan antar variabel yang ditinjau. Penelitian ini dilakukan dengan menambahkan metakaolin dengan kadar 17,5\% dari berat total semen yang diperlukan agar menghasilkan beton High Strength Self Compacting Concrete. Aktivator alkali yang terdiri dari campuran larutan $\mathrm{NaOH}$ dan $\mathrm{Na}_{2} \mathrm{SiO}_{3}$ juga ditambahkan pada campuran beton ini untuk mempercepat reaksi polimerisasi pada metakaolin sehingga dapat mencapai kuat tekan tinggi. Benda uji silinder beton dengan ukuran diameter $15 \mathrm{~cm}$ dan tinggi $30 \mathrm{~cm}$ digunakan pada uji kuat tarik belah, sedangkan benda uji balok beton tanpa tulangan dengan ukuran $40 \mathrm{~cm} \times 10 \mathrm{~cm} \times 10 \mathrm{~cm}$ digunakan pada uji modulus of rupture. Tabel 1 menunjukkan penamaan benda uji sesuai dengan kadar aktivator alkali. 
Tabel 1. Penamaan masing-masing benda uji

\begin{tabular}{cclcc}
\hline No. & Aktivator Alkali & Nama Benda Uji & Umur (hari) & Banyaknya Benda Uji \\
\hline Uji Kuat Tarik Belah & & & \\
\hline 1 & 0 & HSSCC-KTB-MK-AA-0 & 28 & 3 \\
2 & $1 / 2$ & HSSCC-KTB-MK-AA-1/2 & 28 & 3 \\
3 & $2 / 2$ & HSSCC-KTB-MK-AA-2/2 & 28 & 3 \\
4 & $3 / 2$ & HSSCC-KTB-MK-AA-3/2 & 28 & 3 \\
\hline Uji Modulus of $\boldsymbol{R}$ upture & & 28 & 3 \\
\hline 1 & 0 & HSSCC-MOR-MK-AA-0 & 28 & 3 \\
2 & $1 / 2$ & HSSCC-MOR-MK-AA-1/2 & 28 & 3 \\
3 & $2 / 2$ & HSSCC-MOR-MK-AA-2/2 & 28 & 3 \\
\hline & $3 / 2$ & HSSCC-MOR-MK-AA-3/2 & 24 \\
\hline \multicolumn{7}{r}{} \\
\hline
\end{tabular}

\section{Rancang Campuran Beton}

Rancang campuran beton High Strength Self Compacting Concrete (HSSCC) sesuai dengan EFNARC 2005, dengan menggunakan bahan tambah metakaolin 17,5\% dan variasi aktivator alkali. Faktor air semen dan kadar superplasticizer optimum yang digunakan adalah berturut-turut 0,31 dan 1,5\% dari total berat binder. Tabel 2 menunjukkan rancang campuran beton yang digunakan.

Tabel 2. Rancang campuran beton mutu tinggi memadat mandiri

\begin{tabular}{lcccccccc}
\hline Benda Uji & $\begin{array}{c}\text { Aggregat } \\
\text { Halus } \\
\left(\mathbf{k g} / \mathbf{m}^{3}\right)\end{array}$ & $\begin{array}{c}\text { Aggregat } \\
\text { Kasar } \\
\left(\mathbf{k g} / \mathbf{m}^{3}\right)\end{array}$ & $\begin{array}{c}\text { Semen } \\
\left(\mathbf{k g} / \mathbf{m}^{3}\right)\end{array}$ & $\begin{array}{c}\text { Metakaolin } \\
\left.\mathbf{( k g} / \mathbf{m}^{3}\right)\end{array}$ & $\begin{array}{c}\mathbf{N a}_{2} \mathbf{S i O}_{3} \\
\left.\mathbf{( k g} / \mathbf{m}^{3}\right)\end{array}$ & $\begin{array}{c}\mathbf{N a O H} \\
\left(\mathbf{k g} / \mathbf{m}^{3}\right)\end{array}$ & $\begin{array}{c}\mathbf{S P} \\
\left(\mathbf{l t} / \mathbf{m}^{3}\right)\end{array}$ & $\begin{array}{c}\mathbf{A i r} \\
\left(\mathbf{l t} / \mathbf{m}^{3}\right)\end{array}$ \\
\hline HSSCC MK AA-0 & 878,36 & 729,59 & 495,00 & 105,00 & 0,00 & 0,00 & 9,00 & 186,00 \\
HSSCC MK AA-1/2 & 848,75 & 704,99 & 465,00 & 105,00 & 10,00 & 20,00 & 9,00 & 186,00 \\
HSSCC MK AA-2/2 & 848,75 & 704,99 & 465,00 & 105,00 & 15,00 & 15,00 & 9,00 & 186,00 \\
HSSCC MK AA-3/2 & 848,75 & 704,99 & 465,00 & 105,00 & 18,00 & 12,00 & 9,00 & 186,00 \\
\hline
\end{tabular}

\section{Kuat Tarik Belah Beton}

Data yang didapatkan dari pengujian kuat tarik belah dapat dihitung dengan Persamaan [1]. Persamaan ini sesuai dengan SNI 2491:2014.

$f^{\prime} t=\frac{2 P}{\pi L D}$

ft adalah kuat tarik belah (MPa); P adalah beban maksimum $(\mathrm{N})$; D adalah diameter benda uji (mm) dan $\mathrm{L}$ adalah panjang benda uji (mm)

\section{Modulus of Rupture Beton}

Data dari pengujian modulus of rupture dapat diketahui berdasarkan metode center point loading menurut ASTM C293 dan perhitungan dapat dilakukan dengan Persamaan [2].

$R=\frac{3 P L}{2 b d^{2}}$

$\mathrm{R}$ adalah modulus of rupture (MPa); L adalah panjang benda uji (mm); $\mathrm{P}$ adalah beban maksimum $(\mathrm{N})$; $\mathrm{d}$ adalah tinggi benda uji (mm) dan b adalah lebar benda uji (mm)

\section{Pengujian Beton Segar}

Workability pada beton dapat diketahui dengan pengujian beton yang baru dibuat dalam keadaan segar. Terdapat 3 pengujian yang dilakukan pada beton HSSCC berdasarkan EFNARC 2005, yaitu slump flow test, $V$-funnel test, dan $L$ box test untuk mengetahui parameter Self Compacting Concrete yaitu filling ability, passing ability, dan viscosity.

\section{HASIL DAN PEMBAHASAN}

Hasil Pengujian Beton Segar

Tabel 3 sampai dengan Tabel 5 menunjukkan hasil pengujian yang dilakukan pada beton segar melalui slump flow test, $V$-funnel test, dan L-box test pada penelitian ini. Pada slump flow test, semua benda uji dapat memenuhi syarat SCC. 
Kemudian pada l-box test, hanya benda uji dengan kadar aktivator alkali sebesar 3/2 yang tidak memenuhi syarat SCC. Sementara itu, pada $V$-funnel test, benda uji dengan kadar aktivator alkali sebesar $2 / 2$ dan $3 / 2$ tidak memenuhi syarat SCC. Hal ini dikarenakan semakin besar penambahan kadar aktivator alkali, maka beton segar semakin kental dan sulit mengalir.

Tabel 3. Hasil uji slump flow test

\begin{tabular}{|c|c|c|c|c|c|c|c|c|}
\hline \multirow[b]{2}{*}{ Nama Benda Uji } & \multicolumn{8}{|c|}{ Pengujian Slump Flow Test } \\
\hline & $\begin{array}{l}T_{500 \text { rerata }} \\
\text { (detik) }\end{array}$ & Syarat & Keterangan & $\begin{array}{c}\mathbf{D}_{1} \\
(\mathrm{~mm})\end{array}$ & $\begin{array}{c}\mathbf{D}_{2} \\
(\mathrm{~mm})\end{array}$ & $\begin{array}{l}D_{\text {rerata }} \\
(\mathrm{mm})\end{array}$ & Syarat & Keterangan \\
\hline HSSCC - MK AA-0 & 2,31 & \multirow{4}{*}{ 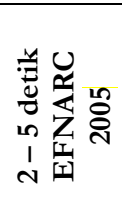 } & $\sqrt{ }$ & 730 & 760 & 745 & \multirow{4}{*}{ 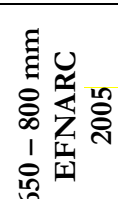 } & $\sqrt{ }$ \\
\hline HSSCC - MK AA- $1 / 2$ & 2,92 & & $\sqrt{ }$ & 720 & 730 & 725 & & $\sqrt{ }$ \\
\hline HSSCC - MK AA- $2 / 2$ & 3,52 & & $\sqrt{ }$ & 720 & 690 & 705 & & $\sqrt{ }$ \\
\hline HSSCC - MK AA- $3 / 2$ & 4,46 & & $\sqrt{ }$ & 680 & 680 & 680 & & $\sqrt{ }$ \\
\hline
\end{tabular}

Keterangan $\sqrt{ }=$ Memenuhi syarat

Tabel 4. Hasil uji L-box test

\begin{tabular}{|c|c|c|c|c|c|}
\hline Nama Benda Uji & $\mathrm{h}_{2}(\mathrm{~mm})$ & $\mathrm{h}_{1}(\mathrm{~mm})$ & $\mathbf{h}_{2} / \mathbf{h}_{1}$ & Syarat & Kesimpulan \\
\hline HSSCC - MK AA-0 & 8,9 & 9,3 & 0,96 & U & Memenuhi Syarat \\
\hline HSSCC - MK AA-1/2 & 8,4 & 9,3 & 0,90 & †乎 & Memenuhi Syarat \\
\hline HSSCC - MK AA-2/2 & 7,9 & 9,7 & 0,81 & $0_{0}^{\infty} Z_{1}$ & Memenuhi Syarat \\
\hline HSSCC - MK AA-3/2 & 5,8 & 10,2 & 0,57 & 厌 & Tidak Memenuhi Syarat \\
\hline
\end{tabular}

Tabel 5. Hasil uji $V$-funnel test

\begin{tabular}{|c|c|c|c|}
\hline Nama Benda Uji & $\begin{array}{l}\text { V-Funnel } \\
\text { (detik) }\end{array}$ & Syarat & Kesimpulan \\
\hline HSSCC - MK AA-0 & 6,87 & & Memenuhi Syarat \\
\hline HSSCC - MK AA-1/2 & 9,39 & 문 & Memenuhi Syarat \\
\hline HSSCC - MK AA-2/2 & 13,57 & l' & Tidak Memenuhi Syarat \\
\hline HSSCC - MK AA-3/2 & 17,46 & 式 & Tidak Memenuhi Syarat \\
\hline
\end{tabular}

Berdasarkan data pada Tabel 3 sampai dengan Tabel 5, dapat diketahui grafik hubungan yang digambarkan pada Gambar 1 sampai dengan Gambar 4. Gambar 1 menunjukkan semakin besar variasi aktivator alkali maka diperlukan waktu yang lebih besar untuk mencapai diameter sebaran $50 \mathrm{~cm}$. Gambar 2 menunjukkan semakin semakin besar variasi aktivator alkali maka diameter sebaran semakin kecil. Gambar 3 menunjukkan semakin semakin besar variasi aktivator alkali maka perbandingan $\mathrm{h}_{2} / \mathrm{h}_{1}$ pada $L$-box semakin kecil. Gambar 4 menunjukkan semakin semakin besar variasi aktivator alkali maka waktu yang diperlukan untuk mengalir pada v-funnel semakin besar.

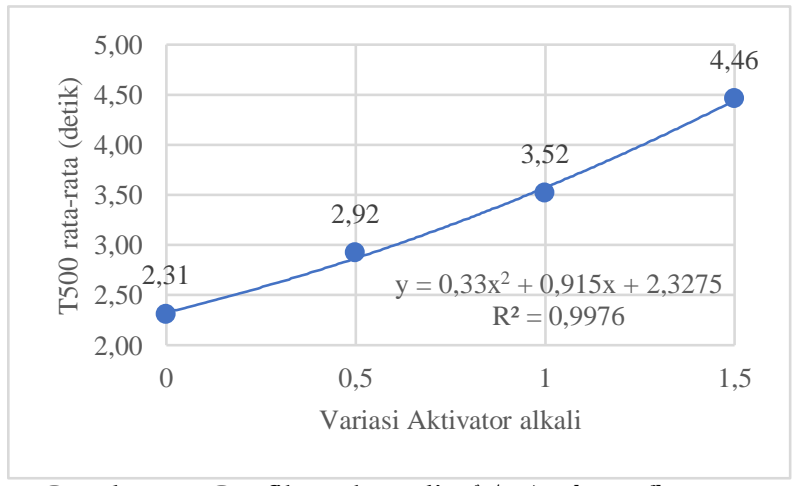

Gambar 1. Grafik waktu alir $\left(\mathrm{T}_{500}\right)$ slump flow test

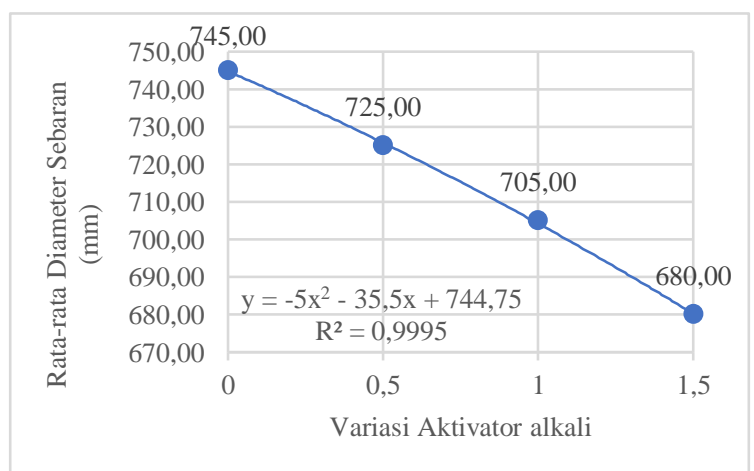

Gambar 2. Grafik diameter rerata slump flow test 


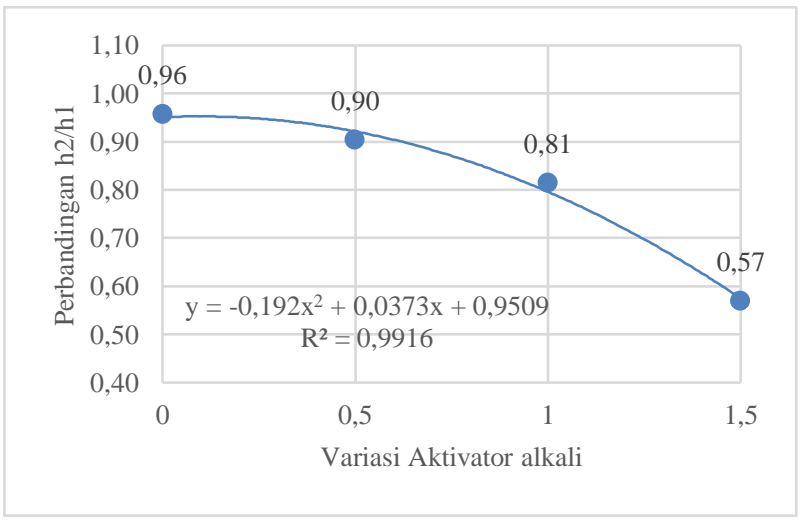

Gambar 3. Grafik nilai $\mathrm{H}_{2} / \mathrm{H}_{1}$ L-box test

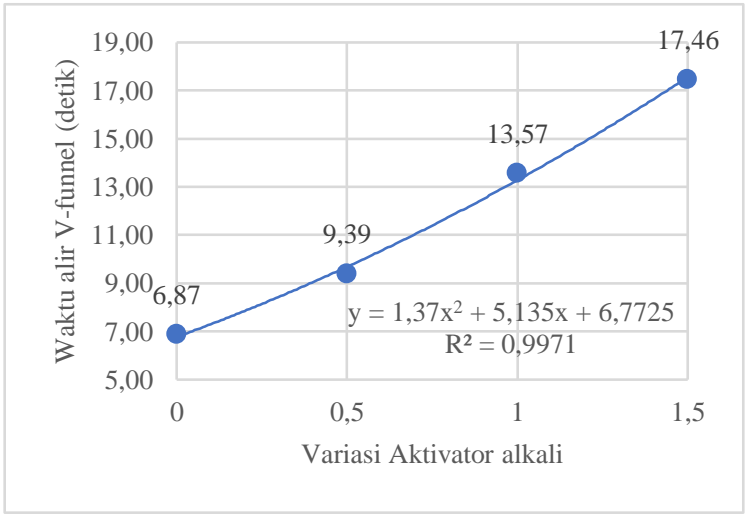

Gambar 4. Grafik nilai waktu alir $V$-funnel test

\section{Pengujian Kuat Tekan Beton}

Hasil uji parameter kuat tekan beton pada umur 28 hari mengutip dari penelitian yang dilakukan oleh Sujati, 2021. Tabel 6 menunjukkan rekapitulasi hasil uji parameter kuat tekan beton rata-rata. Berdasarkan Tabel 6, kuat tekan beton rata-rata tertinggi diperoleh oleh beton dengan variasi penambahan aktivator alkali sebesar 2/2.

Tabel 6. Hasil uji parameter kuat tekan beton umur 28 hari rata-rata

\begin{tabular}{llc}
\hline No. & Nama Benda Uji & Kuat Tekan Beton Rata-Rata (MPa) \\
\hline 1. & HSSCC - MK AA-0 & 41,71 \\
2. & HSSCC - MK AA-1/2 & 43,69 \\
3. & HSSCC - MK AA-2/2 & 46,90 \\
4. & HSSCC - MK AA-3/2 & 44,73 \\
\hline
\end{tabular}

Sumber : Dinar Sujati, 2021

\section{Pengujian Kuat Tarik Belah Beton}

Tabel 7 menunjukkan rekapitulasi hasil uji parameter kuat tarik belah beton HSSCC dengan bahan tambah metakaolin dan variasi aktivator alkali. Keseluruhan variasi penambahan membuat beton mengalami kenaikan nilai kuat tarik belah rata-rata pada beton. Kenaikan tertinggi dicapai oleh beton dengan variasi penambahan sebesar 2/2, dengan kenaikan 14,91\% dari beton tanpa penambahan aktivator alkali, yaitu sebesar 3,09 MPa.

Tabel 7. Rekapitulasi hasil uji parameter kuat tarik belah beton

\begin{tabular}{|c|c|c|c|c|c|c|c|}
\hline Nama Benda Uji & $\begin{array}{l}\text { Kode Benda } \\
\text { Uji }\end{array}$ & $\begin{array}{l}\text { D } \\
(\mathrm{mm})\end{array}$ & $\begin{array}{l}\mathrm{L} \\
(\mathrm{mm})\end{array}$ & $\begin{array}{l}\mathbf{P} \\
(\mathrm{N})\end{array}$ & $\begin{array}{l}\mathrm{f}^{\prime} \mathrm{t} \\
(\mathrm{MPa})\end{array}$ & $\begin{array}{l}\text { f't rerata } \\
(\mathrm{MPa})\end{array}$ & $\begin{array}{l}\text { Kenaikan } \\
(\%)\end{array}$ \\
\hline \multirow{3}{*}{ HSSCC-KTB-MK-AA0 } & $\mathrm{A}$ & 150 & 300 & 185000 & 2,62 & \multirow{3}{*}{2,69} & \multirow[t]{3}{*}{5} \\
\hline & $\mathrm{B}$ & 150 & 300 & 185000 & 2,62 & & \\
\hline & C & 150 & 300 & 200000 & 2,83 & & \\
\hline \multirow{3}{*}{ HSSCC-KTB-MK-AA1/2 } & A & 150 & 300 & 210000 & 2,97 & \multirow{3}{*}{2,85} & \multirow{3}{*}{6,14} \\
\hline & $\mathrm{B}$ & 150 & 300 & 190000 & 2,97 & & \\
\hline & C & 150 & 300 & 205000 & 2,90 & & \\
\hline \multirow{3}{*}{ HSSCC-KTB-MK-AA2/2 } & A & 150 & 300 & 220000 & 3,11 & \multirow{3}{*}{3,09} & \multirow{3}{*}{14,91} \\
\hline & $\mathrm{B}$ & 150 & 300 & 215000 & 3,04 & & \\
\hline & C & 150 & 300 & 220000 & 3,11 & & \\
\hline \multirow{3}{*}{ HSSCC-KTB-MK-AA3/2 } & A & 150 & 300 & 210000 & 2,97 & \multirow{3}{*}{2,97} & \multirow{3}{*}{10,53} \\
\hline & B & 150 & 300 & 225000 & 3,18 & & \\
\hline & C & 150 & 300 & 195000 & 2,76 & & \\
\hline
\end{tabular}

\section{Pengujian Modulus of Rupture Beton}

Tabel 8 menunjukkan rekapitulasi hasil uji parameter modulus of rupture beton HSSCC dengan bahan tambah metakaolin dan variasi aktivator alkali. Keseluruhan variasi penambahan membuat beton mengalami kenaikan nilai 
modulus of rupture rata-rata pada beton. Kenaikan tertinggi dicapai oleh beton dengan variasi penambahan sebesar 2/2, dengan kenaikan 17,39\% dari beton tanpa penambahan aktivator alkali, yaitu sebesar 3,57 MPa.

Tabel 8. Rekapitulasi hasil uji parameter modulus of rupture beton

\begin{tabular}{|c|c|c|c|c|c|c|c|c|c|}
\hline Nama Benda Uji & $\begin{array}{l}\text { Kode } \\
\text { Benda } \\
\text { Uji }\end{array}$ & $\begin{array}{l}\text { P } \\
\text { (kgf) }\end{array}$ & $\begin{array}{l}\mathbf{P} \\
(\mathrm{N})\end{array}$ & $\begin{array}{l}\mathrm{D} \\
(\mathrm{mm})\end{array}$ & $\begin{array}{l}\text { B } \\
(\mathrm{mm})\end{array}$ & $\begin{array}{l}\mathbf{L} \\
(\mathrm{mm})\end{array}$ & $\begin{array}{l}\mathrm{R} \\
(\mathrm{MPa})\end{array}$ & $\begin{array}{l}R \text { rata- } \\
\text { rata } \\
(\mathrm{MPa})\end{array}$ & Kenaikan \\
\hline \multirow{3}{*}{ HSSCC-MOR-MK-AA0 } & A & 690 & 6766,59 & 100 & 100 & 300 & 3,04 & \multirow{3}{*}{3,04} & \multirow{3}{*}{-} \\
\hline & B & 710 & 6962,72 & 100 & 100 & 300 & 3,13 & & \\
\hline & $\mathrm{C}$ & 670 & 6570,46 & 100 & 100 & 300 & 2,96 & & \\
\hline \multirow{3}{*}{ HSSCC-MOR-MK-AA1/2 } & A & 720 & 7060,79 & 100 & 100 & 300 & 3,18 & \multirow{3}{*}{3,27} & \multirow{3}{*}{7,25} \\
\hline & B & 730 & 7158,85 & 100 & 100 & 300 & 3,22 & & \\
\hline & $\mathrm{C}$ & 770 & 7551,12 & 100 & 100 & 300 & 3,40 & & \\
\hline \multirow{3}{*}{ HSSCC-MOR-MK-AA2/2 } & A & 790 & 7747,25 & 100 & 100 & 300 & 3,49 & \multirow{3}{*}{3,57} & \multirow{3}{*}{17,39} \\
\hline & B & 810 & 7943,39 & 100 & 100 & 300 & 3,57 & & \\
\hline & $\mathrm{C}$ & 830 & 8139,52 & 100 & 100 & 300 & 3,66 & & \\
\hline \multirow{3}{*}{ HSSCC-MOR-MK-AA3/2 } & $\mathrm{A}$ & 750 & 7354,99 & 100 & 100 & 300 & 3,31 & \multirow{3}{*}{3,38} & \multirow{3}{*}{11,11} \\
\hline & B & 800 & 7845,32 & 100 & 100 & 300 & 3,53 & & \\
\hline & $\mathrm{C}$ & 750 & 7354,99 & 100 & 100 & 300 & 3,31 & & \\
\hline
\end{tabular}

Hubungan antara Kuat Tekan Beton (f'c) dengan Kuat Tarik Belah Beton (f't)

Tabel 9 menunjukkan nilai pendekatan hubungan antara parameter kuat tekan beton dengan parameter kuat tarik belah beton. Nilai pendekatan atau konstanta diperoleh berdasarkan hubungan parameter kuat tekan dan parameter kuat tarik belah beton rata-rata pada SNI 2847:2019.

Tabel 9. Nilai pendekatan antara parameter kuat tekan beton ( $\mathrm{fc}$ ) dengan parameter kuat tarik belah beton ( $\mathrm{ft}$ )

\begin{tabular}{|c|c|c|c|c|}
\hline $\begin{array}{l}\text { Variasi Perbandingan } \\
\text { Aktivator alkali }\end{array}$ & $\mathrm{f}^{\prime} \mathrm{t}(\mathrm{MPa})$ & $\mathrm{f}^{\prime} \mathrm{c}(\mathrm{MPa})$ & $\sqrt{ } \mathrm{f}^{\prime} \mathrm{c}(\mathrm{MPa})$ & $K=\mathbf{f}^{\prime} \mathbf{t} / \sqrt{ } \mathbf{f}^{\prime} \mathbf{c}$ \\
\hline 0 & 2,69 & 41,71 & 6,46 & 0,42 \\
\hline $1 / 2$ & 2,85 & 43,69 & 6,61 & 0,43 \\
\hline $2 / 2$ & 3,09 & 46,90 & 6,85 & 0,45 \\
\hline $3 / 2$ & 2,97 & 44,73 & 6,69 & 0,44 \\
\hline
\end{tabular}

f'c adalah kuat tekan beton (MPa); ft adalah kuat tarik belah beton (MPa); K adalah konstanta dan $\sqrt{\mathrm{f}} \mathrm{c}$ adalah akar kuat tekan beton $(\mathrm{MPa})$

Berdasarkan hasil nilai pendekatan yang disajikan pada Tabel 9, nilai konstanta untuk semua variasi perbandingan aktivator alkali tidak lebih dari 0,56 sehingga memenuhi hubungan parameter kuat tekan dan parameter kuat tarik belah beton rata-rata, berdasarkan SNI 2847:2019.

\section{Hubungan Kuat Tekan Beton dengan Modulus of Rupture Beton}

Rekapitulasi nilai pendekatan hubungan parameter kuat tekan beton dengan parameter modulus of rupture ditunjukkan pada Tabel 10. berikut. Nilai pendekatan atau konstanta diperoleh berdasarkan hubungan parameter kuat tekan dan parameter modulus of rupture rata-rata pada SNI 2847:2019.

Tabel 10. Nilai pendekatan hubungan parameter kuat tekan (fc) dengan parameter modulus of rupture beton (R)

\begin{tabular}{lllll}
\hline $\begin{array}{l}\text { Variasi perbandingan } \\
\text { aktivator alkali }\end{array}$ & $\mathbf{R}(\mathbf{M P a})$ & $\mathbf{f} \mathbf{c}(\mathbf{M P a})$ & $\sqrt{ } \mathbf{f} \mathbf{c}(\mathbf{M P a})$ & $\mathbf{K}=\mathbf{R} / \sqrt{ } \mathbf{f} \mathbf{c}$ \\
\hline 0 & 3,04 & 41,71 & 6,46 & 0,47 \\
$1 / 2$ & 3,27 & 43,69 & 6,61 & 0,49 \\
$2 / 2$ & 3,57 & 46,90 & 6,85 & 0,52 \\
$3 / 2$ & 3,38 & 44,73 & 6,69 & 0,51 \\
\hline
\end{tabular}

fc adalah kuat tekan beton (MPa); R adalah modulus of rupture beton (MPa); K adalah konstanta dan $\sqrt{\mathrm{f}} \mathrm{c}$ adalah akar kuat tekan beton $(\mathrm{MPa})$ 
Menurut hasil rekapitulasi, nilai pendekatan kuat tekan beton dengan modulus of rupture yang disajikan pada Tabel 10., menurut SNI 2847:2019, semua benda uji memiliki hubungan antara kuat tekan beton dengan modulus of rupture karena menghasilkan nilai konstanta yang tidak lebih dari 0,62.

\section{Hubungan Kuat Tarik Belah Beton dengan Modulus of Rupture Beton}

Tabel 11 menunjukkan hasil nilai pendekatan hubungan parameter kuat tarik belah beton dan parameter modulus of rupture beton.

Tabel 11. Nilai pendekatan hubungan kuat tarik belah beton ( $\mathrm{ft}$ ) dan modulus of rupture beton $(\mathrm{R})$

\begin{tabular}{ccc}
\hline $\begin{array}{c}\text { Variasi perbandingan } \\
\text { aktivator alkali }\end{array}$ & $\begin{array}{c}\text { Rata-rata } \mathbf{f} \mathbf{t} \\
\mathbf{( M P a})\end{array}$ & $\begin{array}{c}\text { Rata-rata } \mathbf{R} \\
\mathbf{( M P a})\end{array}$ \\
\hline 0 & 2,69 & 3,04 \\
$1 / 2$ & 2,85 & 3,27 \\
$2 / 2$ & 3,09 & 3,57 \\
$3 / 2$ & 2,97 & 3,38 \\
\hline
\end{tabular}

Menurut data yang ditunjukkan pada Tabel 11., maka dapat dibuat grafik yang menunjukkan hubungan rerata kuat tarik belah beton dan rerata modulus of rupture beton yang disajikan pada Gambar 5. berikut.

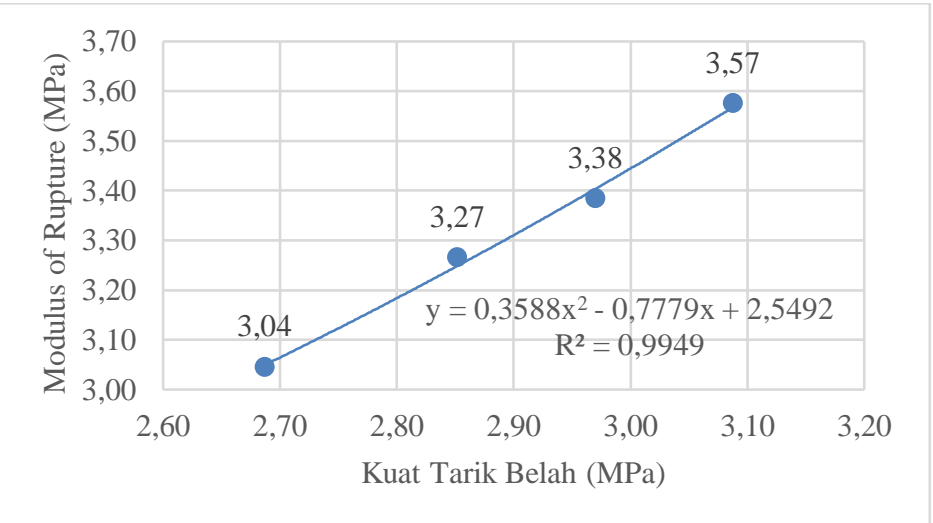

Gambar 5. Grafik hubungan kuat tarik belah beton dengan modulus of rupture beton

Berdasarkan Gambar 5 dapat diketahui rumus empiris yang menyatakan hubungan parameter kuat tarik belah beton dan parameter modulus of rupture beton yaitu $\mathrm{y}=0,3588 \mathrm{x}^{2}-0,7779 \mathrm{x}+2,5492$ dengan $\mathrm{y}$ adalah nilai modulus of rupture beton dan $\mathrm{x}$ adalah nilai kuat tarik belah beton.

\section{Penambahan Aktivator Alkali Optimum pada Pengujian Kuat Tarik Belah}

Untuk mengetahui kadar penambahan optimum aktivator alkali yang menghasilkan beton dengan kuat tarik belah maksimum, dapat menggunakan persamaan regresi garis lengkung berikut :

$y=-0,2828 x 2+0,6411 x+2,6657$

kemudian persamaan tersebut dideferensialkan sehingga didapat :

$$
\begin{aligned}
\frac{d y}{d x} & =0 \\
2(-0,2828) \mathrm{x}+0,6411 & =0 \\
-0,5656 \mathrm{x}+0,6411 & =0 \\
\mathrm{x} & =\frac{-0,6411}{-0,5656} \\
& =1,1335
\end{aligned}
$$

Setelah diketahui nilai $x$, maka nilai y dapat diketahui dengan cara mensubstitusikan nilai $\mathrm{x}$ ke persamaan :

$\mathrm{y}=-0,2828 \mathrm{x} 2+0,6411 \mathrm{x}+2,6657$

$y=-0,2828(1,1335) 2+0,6411(1,1335)+2,6657$

$\mathrm{y}=3,03 \mathrm{MPa}$ 
Berdasarkan perhitungan tersebut, dapat disimpulkan bahwa presentase penambahan variasi aktivator alkali terhadap nilai kuat tarik belah yang optimal adalah sebesar 1,1335 atau perbandingan $\mathrm{Na} 2 \mathrm{SiO} 3 / \mathrm{NaOH}=2,267 / 2$. Sementara itu, nilai kuat tarik belah beton yang dicapai sebesar 3,03 MPa.

\section{Penambahan Aktivator Alkali Optimum pada Pengujian Modulus of Rupture}

Untuk mengetahui kadar penambahan optimum aktivator alkali yang menghasilkan beton dengan modulus of rupture maksimum, dapat menggunakan persamaan regresi garis lengkung berikut :

$\mathrm{y}=-0,4119 \mathrm{x} 2+0,8826 \mathrm{x}+3,0155$

kemudian persamaan tersebut dideferensialkan sehingga didapat :

$$
\begin{aligned}
\frac{d y}{d x} & =0 \\
2(-0,4119) \mathrm{x}+0,8826 & =0 \\
-0,8238 \mathrm{x}+0,8826 & =0 \\
\mathrm{x} & =\frac{-0,8826}{-0,8238} \\
& =1,0714
\end{aligned}
$$

Setelah diketahui nilai $\mathrm{x}$, maka nilai y dapat diketahui dengan cara mensubstitusikan nilai $\mathrm{x}$ ke persamaan :

$\mathrm{y}=-0,4119 \mathrm{x} 2+0,8826 \mathrm{x}+3,0155$

$\mathrm{y}=-0,4119(1,0714) 2+0,8826(1,0714)+3,0155$

$\mathrm{y}=3,49 \mathrm{MPa}$

Berdasarkan perhitungan tersebut, dapat disimpulkan bahwa presentase penambahan variasi aktivator alkali terhadap nilai modulus of rupture yang optimal adalah sebesar 1,0714 atau perbandingan $\mathrm{Na} 2 \mathrm{SiO} 3 / \mathrm{NaOH}=2,1428$ / 2. Sementara itu, nilai modulus of rupture yang dicapai sebesar 3,49 $\mathrm{MPa}$.

\section{SIMPULAN}

Berdasarkan penelitian yang telah dilakukan, kajian kuat tarik belah dan modulus of rupture pada beton mutu tinggi memadat mandiri dengan bahan tambah metakaolin dan variasi aktivator alkali dapat disimpulkan bahwa terjadi penurunan workabilitas beton saat dilakukan penambahan metakaolin 17,5\% dan variasi aktivator alkali pada rancang campuran beton mutu tinggi memadat mandiri, namun masih dapat memenuhi beberapa parameter SCC. Nilai kuat tarik belah beton dan modulus of rupture meningkat setelah dilakukan penambahan metakaolin 17,5\% dan variasi aktivator alkali bila dibandingkan dengan beton normal yang hanya ditambahkan metakaolin 17,5\%, namun akan menurun setelah melewati kadar optimum. Dalam campuran ini, nilai kuat tarik belah maksimum yang dapat dicapai oleh beton adalah saat dilakukan penambahan aktivator alkali variasi 2/2, dengan nilai 3,09 MPa, sedangkan nilai modulus of rupture maksimum yang dapat dicapai oleh beton adalah saat dilakukan penambahan aktivator alkali variasi 2/2, dengan nilai 3,57 $\mathrm{MPa}$.

\section{UCAPAN TERIMAKASIH}

Ucapan terima kasih yang pertama ditujukan kepada Allah SWT, atas rahmat-Nya selama penelitian ini. Selanjutnya, ucapan terima kasih diberikan kepada Bapak Wibowo, S.T., DEA dan Ibu Dr. Endah Safitri, S.T., M.T selaku dosem pembimbing yang telah memberikan arahan dalam penelitian ini. Penulis juga berterima kasih kepada kedua orang tua yang telah mendukung. Selain itu, penulis juga berterima kasih kepada staff / laboran Laboratorium Bahan Konstruksi dan Rekayasa Struktur Program Studi Teknik Sipil Fakultas Teknik Universitas Sebelas Maret Surakarta dan rekan kelompok penelitian atas bantuannya dalam penyelesaian penelitian ini.

\section{REFERENSI}

Dharmawan, E. A., et al., 2017, “Kajian Pengaruh Variasi Komposisi Metakaolin terhadap Parameter Beton Memadat Mandiri dan Kuat Tekan Beton Mutu Tinggi", Jurnal Matriks Teknik Sipil.

EFNARC, 2005, "Specification and Guidelines for Self-Compacting Concrete".

Nurkhasan, S. S., et al., 2020, "Pemenuhan Kriteria Beton Memadat Mandiri dengan Variasi Metakaolin terhadap Kajian Kuat Tekan Tinggi dan Modulus Elastisitas", Jurnal Matriks Teknik Sipil.

Risdanareni, P., et al., 2014, "Pengaruh Molaritas Aktifator Alkalin Terhadap Kuat Mekanik Beton Geopolimer dengan Tras sebagai Pengisi”, Seminar Nasional X, Surabaya.

Standar Nasional Indonesia, 2000, “(SNI) 03-6468-2000: Tata Cara Perencanaan Campuran Tinggi dengan Semen Portland dengan Abu Terbang". 
Standar Nasional Indonesia, 2002, “(SNI) 03-2491-2002: Metode Pengujian Kuat Tarik Belah Beton”.

Standar Nasional Indonesia, 2014, ”(SNI) 2491-2014: Metode Uji Kekuatan Tarik Belah Spesimen Beton Silinder”. Standar Nasional Indonesia, 2019, "(SNI) 2847-2019: Persyaratan Beton Struktural untuk Bangunan Gedung dan Penjelasan".

Sujati, D., 2021, "Kajian Kuat Tekan dan Modulus Elastisitas pada Beton Mutu Tinggi Memadat Mandiri dengan Bahan Tambah Metakaolin dan Variasi Perbandingan Alkali Aktivator", Universitas Sebelas Maret, Surakarta.

Wibowo., et al., 2018, "Kajian Pengaruh Variasi Metakaolin terhadap Parameter Beton Memadat Mandiri Mutu Tinggi”, Jurnal Matriks Teknik Sipil.

Wibowo., et al., 2018, "Study on effect of variations of meta-kaolin addition on Self-Compacting parameter of High Strength Concrete", International Journal of Integrated Engineering.

Wibowo., et al., 2019, "Kajian Kuat Tarik Belah pada Beton Mutu Tinggi Memadat Mandiri dengan Variasi Komposisi Metakaolin dan Superplasticizer Masterease 3019", Jurnal Matriks Teknik Sipil. 